\title{
INFANT WELFARE: METHODS OF ORGANIZATION AND ADMINISTRATION
}

\author{
CHARLES RICHMOND HENDERSON \\ The University of Chicago
}

\section{III}

\section{GERMANY ${ }^{\text {I }}$}

Germany is not frightened into interest by anxiety about diminution of birth rate, though this is falling; but thoughtful leaders are scandalized by the annual death roll of 400,000 infants, about one-fifth of all that are born, a condition which they regard as unworthy of a civilized people of the first rank. In the years I90I to I904, of I,000 persons, I97.5 died at the age $\circ$ to I year; 20.5 from one to five years of age; 4.3 from five to ten years; 2.6 from ten to fifteen years. More than one-third of all deaths in the German Empire fell in the first year of life. Here as elsewhere poverty is cause of a high rate of infant mortality. Among

${ }^{x}$ Bibliographies are found in Würtz and Tugendreich.

The following publications have been consulted for this article: Die Mutter- und Säuglingsfürsorge, von Dr. Gustav Tugendreich, Stuttgart, I9I0; Das Vormundschaftsrecht des biirgerlichen Gesetzbuches, Wilhelm von Blume, Berlin, 1904; Enzyklopädisches Handbuch des Kinderschutzes und der Jugendfürsorge, von Dr. phil. Th. Hiller, Dr. jur. Fr. Schiller, Dr. med. M. Taube, Leipsic, I9ıг; Ergebnisse der Säuglingsfürsorge; Dr. Arthur Keller, Leipsic, I908; Milchhandel und Milchregulation, von Prof. Dr. Arthur Schlossmann, Wiesbaden, 1909; Säuglingsfïrsorge und Kinderschutz in England und Schottland, von Prof. Dr. A. Keller, I9I1; Die Milch in Gesetz und Rechtsprechung, von Kremers und Schlossmann, I909; Die Stilhungsnot, von Dr. med. Agnes Blum, I909; Die Nahrungsmittelkontrolle durch den Polizeibeamten, von Dr. W. Bremer, Berlin, ı9ıо; Die Bedeutung der Berufsvormundschaft für den Schutz der unehelichen Kinder, von Dr. Chr. J. Klumker und Dr. Othmar Spann, Dresden, I905; Zur Frage der Vormundschaft; Berichte der dritten Tagung deutscher Berufsvormünder, Dresden, I908; Die Organisation der Jugendfïrsorge, Bericht von Dr. Georg Schmidt, 92 Heft, Schriften des deutschen Vereins für Armenpflege und Wohltätigkeit; Leipsic, I9ıо; Vol. IV, IV Congresso internazionale d'assistenza pubblica e privata, Milan, I908; Kinderpflege-Lehrbuch, von Dr. med. Arthur Keller und Dr. med. Walther Birk, Berlin, I9I r. Veröffentlichungen des Vereins für Säuglingsfürsorge im Regierungsbezirk Düsseldorf, herausgegeben von Prof. Dr. Schlossmann und Dr. Marie Baum (C. Heymann Verlag, Berlin); Satzung der Zentrale für Säuglingsfürsorge in Bayern, Munich, 1909; Zeitschrift für Säuglingsfïrsorge, von Prof. Dr. Bruno Salge, und Prof. Dr. Arthur Schlossmann, Leipsic, Verlag A. Barth. A Study of the Display of the International Hygienic Exposition at Dresden, August, I9II, was helpful. Most of all, many delightful hours, during several weeks, with Dr. Taube and Bürgermeister Dr. Weber at Dresden. The municipal authorities of German cities generously and courteously furnished me the most recent reports and regulations. 
the poor the conditions of the dwelling are vicious; the women are worn out by hard toil; nurslings are deprived of mother's breast and care. Illegitimate children suffer most; fortunately their number is gradually decreasing; in I853-57 it was II.05 per cent, in I905 only $8.5^{2}$ per cent of all births. Natural feeding, however, seems to have diminished. In Berlin in 1885 , the infants which had mother milk were 55.2 per cent of all; in I905 only $3 \mathrm{I} .3^{\mathrm{I}}$ per cent. The diseases of which nurslings die in German-speaking countries are the same as those found elsewhere.

The point of view has radically changed in recent years. Formerly the death of a child was regarded as a merely individual loss and sorrow; now it is seen that the entire nation is concerned, and the problem becomes one of social hygiene, and of politics. The medical men show that a high infant mortality raises the number of births and decreases the intervals between confinements, and this causes physical weakness of the mothers and further defects in offspring. Once it was imagined that a high rate of infant mortality was Nature's method of weeding out the unfit; now it is known that the survivors are not always superior, and that they are injured by the same evil conditions which slew their brothers and sisters. The voice of Nature is raised against a policy of leaving all to mere natural selection. ${ }^{\mathrm{I}}$

Germany has made itself famous for its broad system of amelioration, although still far from its goal. Its cities have developed a vigorous policy in respect to the habitations of working people, provisions for air, light, cleanliness, and abundant supply of good water. Owing to the rapid growth of population and its concentration in cities the difficulties are enormous. Private associations and state authorities have put forth efforts, by education and police control, to reduce the ravages of venereal diseases, which are so dangerous to infancy.

While general improvement in income and in physical conditions is an immense though indirect aid to infant welfare, the nation must also directly protect mothers. From the moment of conception to the time of weaning, the infant is immediately and physiologically dependent on the mother, and whatever injures

× A. Würtz, Säuglingsschutz, Stuttgart, I9ro. To this book the writer owes very much. 
the mother has some deleterious effect on the child. It has long been known that too prolonged toil exhausts the vitality of girls and adult women so that their children, if not still-born, start life with heavy handicap. Recent legislation has secured for German working women a maximum day of to hours. The former weekly maximum of 65 hours is now reduced to 58 hours, with the requirement that on the day before Sundays and festivals the day shall not exceed 8 hours and shall not extend beyond 5 o'clock in the afternoon. This law gives relief to 300,000 of the $1,300,000$ factory women. For pregnant women this is an immense gain, and the increased leisure gives a chance for making the little homes more attractive to the men.

The new law secures to all women II hours of unbroken rest at night; formerly night work was forbidden only to girls under sixteen years. A girl or woman fully employed in a factory is not permitted to take in additional work to be done at home.

\section{MATERNITY INSURANCE}

The loss of customary income, in families where the wages of the wife are necessary to maintain even a low standard of living, brings with it anxiety, distress, depression, and deprivation of necessary food. This loss immediately affects the development of the foetus and the milk supply for the babe. Bachimont found, in the case of women who rested before confinement, an average pregnancy of 269 days, while the period with women who worked up to confinement was only 247 days. Pinard found that the babes of women who left work two or three months before confinement weighed at least 300 grams more at birth than the infants of women who remained at their task to the last hour. When the law prescribes rest before and after confinement it is practically impossible to enforce it when no provision is made for their income during the period of enforced rest. Either savings, charity, or insurance funds must assure support. Savings do not exist, in the case of the very poor families; charity is humiliating and uncertain; only by insurance can working women be made certain of care while they cannot go to the factory. As a matter of fact the pregnant women of Germany, Austria, and Switzerland are com- 
pelled to work up to the last hour. In all these three countries legislation provides for the mother after confinement, though inadequately. By the German law of December 28, I908, the period of support by the sickness insurance fund was lengthened to eight weeks.

The German Union for the Protection of Nurslings, in May, I9Io, voted these recommendations to the Imperial Council and Legislature: first, a weekly benefit at the rate of the ordinary sickness indemnity for eight weeks, of which at least six must be after the confinement; second, the service of midwives and medical treatment of complaints of pregnancy; third a support of the pregnant woman at the sickness rate, for six weeks, if she is unable to work; fourth, money for nursing, at same rate, for twelve weeks, if the mother nurses her child.

As the German maternity insurance is not obligatory on the funds, and many associations have neglected to provide these benefits, over 500,000 German women are left unprotected. Würtz justly criticizes a law which assures indemnities to inebriates and dissolute persons, but refuses them to women who are performing a physiological and social function of high importance. The eloquent Friedrich Naumann said: "Men invent machines, women bring men into the world; men shape weapons, while in the arms of women soldiers are reared. Men rule, but women render the highest service to the nation, since only peoples with efficient mothers push their way. Mothers are the conquering element. When motherhood becomes weak in a nation, culture is no longer useful. The sinking down of mothers is the fall of the people, the descent into senility." To provide adequate support the optional law should, in the opinion of well-informed leaders, be made obligatory on all the funds. Sickness insurance must include maternity indemnities, because the illness of the wife has almost as serious consequences in the home as that of the men.

\section{MIDWIVES}

It is often said in America that the midwives of Germany are so carefully educated and supervised that they can be trusted to

${ }^{x} \mathrm{P}$. Mayet, Der Schutz von Mutter und Kind durch reichsgesetzliche Mutterschafts- und Familienversicherung (rgrr). 
take the place of obstetricians. This is gross exaggeration although it is true that these women receive much attention from government and from the medical profession. No one thinks of abolishing at once the use of midwives, a custom deeply rooted in the sentiments of the people. It is generally conceded that public health demands the professional training of women for this service. Where the woman is too poor for such help at confinement, the communes provide means.

\section{CARE OF MOTHERS AFTER CONFINEMENT}

After the doctor or midwife has fulfilled the professional duty of aiding delivery, the mother and her household frequently still require outside assistance. The mother is too weak to bathe and dress her babe and see that the other children and the house are properly cared for. If the mother, urged by anxiety for her household, goes about her work too soon after confinement, she endangers the health and life of her babe and may lay the foundation for female disorders and lifelong invalidism and suffering. To meet this situation the poor-relief authorities in some German cities have trained housekeepers who are sent into indigent families under pay of the public. Associations of charitable ladies furnish baby clothing and articles convenient for the mother; but private charity is local and uncertain.

\section{CARE OF MOTHER AND CHILD IN INSTITUTIONS ${ }^{x}$}

There is great need of refuges, especially for unmarried women, during later pregnancy. Domestics are generally dismissed when their condition is discovered, and in a great city they are in danger of falling into the hands of procurers who know how to utilize despair. Girls are often thrust out from their own families under such circumstances. Germany has some institutions connected with clinics and schools for midwives, but the supply is not sufficient. The only municipal establishment of this kind is at Leipsic. Outdoor relief will not take the place of such houses of refuge.

MATERNITY HOSPITALS

Germany makes better provision for women at the period of confinement; even local administration districts have their mater-

' Würtz, op. cit., 34, 42; Tugendreich, 223-24. 
nities, and the schools for midwives as well as medical schools stimulate their organization. Yet Dr. Marie Baum showed (I902) that in Germany there were only 39 homes for confinement, with a total of roo beds, while yearly there are about 200,000 illegitimate births, not to speak of the great army of indigent married mothers who need the facilities of such institutions. ${ }^{x}$

\section{HOMES FOR MOTHERS AND INFANTS}

The function of such institituons is to avoid premature separation of mother and child, especially in the case of unmarried mothers who have no family protection. The maternity hospital cannot retain the woman longer than about ten days, while the babe needs constant mothering for at least a year. In a home at Berlin-Schoeneberg the mother may be kept even two years. After the first few months of uninterrupted breast-feeding the mother may leave her infant during the day and earn her living by going out to do suitable work.

\section{LEGAL PROBLEMS OF THE CHILD}

Of all human beings the little child most needs the vigilant and continuous supervision of the state and a definite status in relation to parental obligations. In Germany, as elsewhere, the rights of the legitimate child are clearly defined; the parents are required to maintain and educate their children and guard their property interests. ${ }^{2}$ If the parents are unable, through mental defect or destitution, to meet their duties, the state names a substitute or offers financial aid in poor relief.

The case of the illegitimate child is more complicated and difficult. But here the life and health of the child are in jeopardy in greater degree, and its legal rights ought to be defined and enforced with utmost care. The death rate among illegitimate infants is always and everywhere high even under the best conditions. The fundamental legal principle is stated in the secs. I705 ff. of the Civil Code. The illegitimate child has, in relation to the mother and to the relatives of the mother, the legal position of a legitimate child. It bears the family name of the mother. If the

${ }^{x}$ Tugendreich, op. cit., 225.

${ }^{2}$ Civil Code, secs. I627, I630, I632. 
mother changes her name by marriage, the child bears the family name which the mother had before the marriage; but the husband may go before a civil officer and give his name to the child and have a record made. The mother has not parental authority over the child, but must care for it. The guardian represents legal authority over the child. The father of the illegitimate child is under legal obligation to provide for the maintenance of the child, in a manner suitable to the social position of the mother, until it is sixteen years of age. This includes all the means of life, cost of education and training for a life calling. If the child is so physically or mentally defective that it is incapable of self-support, the father must continue his support beyond the sixteenth year. ${ }^{\mathbf{x}}$ The costs of maintenance are payable in money (pension), quarterly in advance.

Careful regulations of adoption and of guardianship are contained in the Civil Code.

The requirement that the father and mother of the illegitimate child are before all others responsible for its care, support, and education is made in the interest of the infant itself as well as of public economy and morality.

\section{GUARDIANSHIP $^{2}$}

The development of this institution in Germany deserves careful study. Naturally, when so many motives conspire to cause neglect of the unwanted illegitimate infant there is great danger of its suffering in health and character. The state protects the legal rights of the child through guardianship. ${ }^{3}$ A minor is placed under a guardian when it is not already under parental authority, or when the parents are not entitled to have charge of his interests, or when his family relations are unknown. The guardian is appointed by the local court (Amtsgericht) sitting as court of guardianship (Vormundschaftsgericht). The first choice of guardian for an illegitimate child is the mother's father; but the mother may be named. The Communal Orphans' Council has a certain right of supervision over wards and their guardians, and it informs

'Sec. $1603, A b$. x.

"See my article in the issue of the Am. Med. Association, September, I9I I, p. I078, on the Leipsic system and its working and results.

3 "Vormundschaft," Civil Code, secs. I773 ff. 
the court of any negligence or dangers. The members of these councils serve without pay, as do the visitors of the poor-relief boards. The position of guardian of an illegitimate child is difficult, and the relatives of the mother are often ignorant of law and unable to protect the interests of the child. It is also very difficult, in fact impossible, for the court to know what becomes of its wards when there are scores and hundreds of guardians scattered over a wide area and moving from place to place. Hence a system of concentrated responsibility has grown up, under the name of the professional guardianship (Berufsvormundschaft), which requires special study since it has become quite general in German cities and has produced excellent results.

Professional guardianship of illegitimate and abandoned infants. ${ }^{x}$ The local "communal council of orphans" has existed-on paperfor some time, but has been a disappointment. It has not central control, continuous oversight, professional skill, responsibility. It is often a useful auxiliary of municipal officials, but it lacks efficiency and reliability unless closely watched. To secure an individual guardian often consumes six or eight weeks; meantime a feeble babe is likely to die from lack of care and food. Prompt action is of the essence of effective guardianship. Most of the relations of the illegitimate infant are incapable of caring for the child; they lack knowledge or interest or both. The unmarried mother is frequently a person of feeble mind and will; her parents may be quite willing to have the unwelcome baby die.

The Civil Code in Germany permits a corporation to be guardian, as a charitable association or institution, and this is often the way chosen.

Dr. Taube, a pediatrist of Leipsic, found the guardianship there defective, and sought a way of procuring immediate support by the father of the illegitimate infant. In 1885 he proposed to give to the Children's Office (Ziehkinderamt) the duty of guardianship, and in 1886 the city poor-relief board adopted his plan. It continues to work well and the idea has been taken up in other cities.

"Articles "Ziehkinder" and "Berufsvormundschaft" in Enzyklopädisches Handbuch des Kinderschutzes und der Jugendfürsorge, Leipsic, rgIr. G. Tugendreich, Die Mutter- und Säuglingsfürsorge, pp. $42 \mathrm{Iff}$. 
The tasks of individual and family care of neglected infants.Tugendreich insists that the foundling hospital and maternity must be regarded as a temporary shelter for the medical examination of infants, for hospital treatment of the sick, and as a center for the selection and control of families where infants are placed for care.

The boarding-place must be carefully selected, the costs must be paid, and the surroundings and treatment continuously supervised.

Not only infants of unmarried mothers supported at public cost, but all illegitimate babies, and even those of married women and widows who receive poor relief, should be under control. Infant mortality increases where such supervision is lacking; but only a few cities have gone as far as is required, owing to absence of enabling legislation.

The cost of care in foster-families varies from city to city. The Society for Protection of Children in Frankfort requires of the father 25 marks monthly from the first to the sixth year, and 30 marks from the seventh to the sixteenth year; but this will not cover medical treatment, clothing, baby wagons, etc. Berlin pays for foster-children $2 \mathrm{I}$ marks per month, and for those needing special care 30 marks, besides clothing and medical relief. Taube, on the basis of an experience of thirty years, estimates 2.30 marks per week for care, but would give the foster-mother for her labor and sleepless nights 4 marks per week. Many poor-relief boards give only Io-r 2 marks monthly, which is too little and leads to frequent and injurious changes. Some boards even let out the poor waifs to the lowest bidder.

Supervision of placing out.-During the first year this is chiefly medical. In Leipsic the foster-mother must report the first week to the city physician's office; during the following week a physician or "supervising lady" (salaried) visits the house to inspect the conditions and give directions. Later the infant is brought regularly for the consultation.

It is the opinion of German experts that the women who assist the physicians in supervision should be properly paid. They need training under medical direction in hospitals or homes for infants. 
Volunteers are not reliable. This demand is not always accepted by the honor officers of poor relief. The usual pay for these visitors, who come from the educated classes, is $800-1200$ marks per year, with carfare paid. Leipsic has 20 such supervisors, Dresden 3, Halle a.S. 4, Berlin (in I906) 20.

Results.-Tugendreich (op. cit., 428) says that the supervisors are interested and reliable; the foster-mothers, usually sincere and earnest, are generally women married to men who follow a trade. Increased mortality follows frequent changes. The best results are obtained where there is only one central authority to secure support, legal protection, physical care. The care of infants in peril will never be complete until there is an unbroken network of consultations throughout the nation, under one central direction, with one set of records, so that no infant can be secretly removed from supervision and lost from sight. An imperial law has been demanded, so that the method may be uniform and complete.

One great advantage of the public and professional guardianship is that the parents of illegitimate infants are more likely to marry and legitimate the child. Even when this cannot be brought about, the fathers can be brought to pay for support. This tends to foster sexual morality by enforcing responsibility for consequences.

In I905 the office in Leipsic collected 55,000 marks from the fathers in large sums, and 125,212 marks in smaller sums by voluntary contributions or pledges of wages, without lawsuits. Strasburg, from October, I902, to March, I905, secured voluntary contributions in $8 \mathrm{r} .5$ per cent of all cases and in $\mathrm{I} 8.5$ per cent the complaint was enforced by process.

The professional or public guardianship exists at Leipsic, Frankfort, Halle, Dortmund, Strasburg, Dantsic, Mühlhausen, and Colmar. Zürich was the first Swiss city with a public guardian.

In Austria the guardianship is usually in the hands of the institutions where the child is placed. The right of administration is usually enforced only after the child leaves the institution; then it is too late to be of value. An exception is found in the foundlings' home of Steiermark in Graz, and that in Prague, 
since the year 1905 , where the paternity of the illegitimate infant is discovered if possible, and the father is required to perform his duty. While the first cost of this method is considerable, the sum collected from the parents relieves the poor funds.

There is a movement to bring all these agencies into federation in order to develop the forms of administration, care for cases abroad, and secure the desirable legislation.

Consultations.-Guardianship, which is primarily designed to supervise economic and legal interests, must always be supplemented by medical supervision, which is well organized in many German cities, as Leipsic, Berlin, Colmar, Dresden, Dantsic, Hamburg, Halle, Metz, Mühlhausen, and Strasburg. Two agencies are indispensable, the physician for foster-children and the lady assistants. The physician, in the better systems, is in control of the selection and supervision of foster-mothers and of the methods of caring for the children. The mother is required, as soon after confinement as is safe, to bring her babe to the office of the physician where it is weighed, examined, and directions are given. A card is made out for each infant and all changes in weight and condition are noted. Breast-feeding is urged, where it is possible. The mother or foster-mother is thus educated for her task, and the consultation (Fürsorgestelle) becomes a "school for mothers."

A striking proof of the advantage of this method is shown in Strasburg. In the year I90I, of the legitimate children I8. I per cent and of the illegitimate nurslings 28. I per cent died. After the city control was introduced, in I908, I6.4 per cent of the legitimate children died and 18.3 per cent of the illegitimate; the improvement in the case of the latter was more marked than that of the former because of the better medical control.

The inspectors (Aufsichtsdamen) are an essential factor. "Women, by gift of nature and innate tenderness, are especially adapted to this work, and experience teaches that educated and trained women can meet the demands of the position" (Würtz). The training can best be given in a hospital for nurslings. The mothers and foster-mothers do not always like this careful supervision, and legal authority must sustain the medical directions. The nurslings which are concealed from inspection are in the great- 
est danger, as those placed in the country. "Only the creation of a unified organization of the entire foster-care system for the empire, and with that extension of medical supervision over the whole land, can prevent the secret treatment of illegitimate children."

It is desirable to have a central bureau for the record of homes suitable and available for care of infants. But it does not seem wise to accept a foster-home from a general list of licensed persons; each case must be carefully inspected with reference to its adaptation to the particular child.

The municipal office of Dr. Taube in Leipsic (since I883) has stimulated the establishment of consultations not only for unmarried mothers but for others. The consultations of Dr. Budin (after I893) had great influence in Germany. ${ }^{x}$ At first many thought it would be enough to provide pure milk for foster-infants; but gradually it became clear that the first effort must be directed to secure breast-feeding wherever practicable; that milk stations are secondary and auxiliary, and that they may even be evil unless placed under rigorous and exact medical control. This policy includes medical advice, household supervision of nurse and nursling, premiums to encourage breast-feeding and help the needy, and, in the last resort, provision of pure milk under careful supervision.

The arrangements for the consultation are not different from those in use in other countries. The whole aim differs from that of a clinic, which is to treat disease, while the consultation is to prevent sickness by a thorough control of physical and economic conditions and direction of the nurse.

So far as possible the consultations should be separated from poor relief and treated as a school of mothers in the community. The wives of self-supporting men should be free to bring their infants and avail themselves of the instruction. Such people are not yet willing to pay a doctor unless the child is already sick and in distress. Many doctors find at best that it is difficult to induce mothers to come for advice regularly and long enough to secure the best results; and so various substantial inducements must be offered. Perhaps some day in the future the expert advice of

' See my article on French methods, Am. Journal of Sociology, January, rgr 2. 
physicians will be appreciated and paid for, to prevent sickness, and the introduction of the consultation will quicken this tendency.

\section{PREMIUMS FOR BREAST-FEEDING}

Specialists in Germany agree that breast-feeding is necessary to the best development of the child. Unfortunately it is widely neglected and its importance not understood. It has been found that many mothers who imagine they cannot furnish milk can increase the secretion by prolonged trial under medical direction. Not only does natural feeding diminish mortality but increases the vigor of the child. Legal compulsion to nurse is not practicable, and maternity insurance is still a dream of the future. Meantime palliatives offer some relief and experiments are tried. Würtz mentions (p. 70) the Still- und Milchkasse opened by Siegfried Weiss at Vienna in 1905 . The women pay certain dues into a fund and when the baby comes they receive help. Dr. Alf. Fischer in Karlsruhe established a Mutterschutzkasse with the same purpose.

Charlottenburg gives food to poor pregnant women several weeks before confinement. In I904, 308 expectant mothers were aided, at a cost of 4,760 marks.

Premiums to mothers for breast-feeding is one means of securing the desirable result. Berlin pays yearly for this object 80,000 marks, Charlottenburg 28,000 marks, Leipsic 18,000, Freiburg 9,000, Karlsruhe 6,000, Strasburg 4,000, Bruchsaal 3,000, etc. The condition of receiving the premiums is that the mother present herself periodically with her baby for medical advice. The doctor pays the premium in money. In some charitable societies the money is paid by laymen - a doubtful practice; it should be under direct medical control. Thus far the premiums ( $\mathrm{I}$ to 6 marks per week) have not been large enough to keep mothers from work for wages outside the home; but the premiums do prolong the time of breast-feeding and of medical control.

In some places midwives are encouraged by premiums for success in inducing mothers to continue natural feeding. Leipsic pays out $\mathrm{I}, 000$ marks annually for this purpose. State and municipal authorities have entered upon the policy of requiring employers of married women to provide rooms where mothers may nurse their 
infants at certain intervals. The commune pays for physician and nurses. ${ }^{x}$

\section{SUPPLY OF MILK ${ }^{2}$}

Impure milk is one of the considerable causes of infant mortality. Various methods of providing pure milk have been put to test: sterilizing apparatus and chilling methods. But, whatever the method, the poor cannot pay the price; public or private charity must intervene; and the danger always lurks at the door that people will substitute artificial for natural food; and this is so disastrous that many almost question the wisdom of trying to furnish cow's milk. Würtz insists that no milk station should be opened without strict medical control, and that money is best expended on consultations where women are taught and encouraged to give nature's own food.

Germany has by no means attained perfection in the quality of the milk sold in the general market. The pure-food laws of Germany and Austria aid to a certain degree, and measures for preventing diseases in cattle are helpful. More special laws and regulations are left to states and municipalities. In Switzerland the cantons control this matter.

In Germany the standards employed have been summarized by Schlossmann: (I) a certain fat content for full milk-2, 3, 3.5 per cent; it should not be under 3 per cent; (2) a certain specific gravity; (3) freedom from dirt; (4) milk to be fresh; (5) milk must not curdle in cooking, within 3 hours after purchase; (6) the quantity of acid is regulated; (7) temperature is under rules; in Breslau milk in the wagon must not be above $20^{\circ} \mathrm{C}$. Cassel requires immediate reduction after milking to $10^{\circ} \mathrm{C}$. Many regulations prescribe methods of treating the cow and of milking. Cassel requires that all cows shall be kept clean; the udders must be washed before milking and the milkers must be clean. The cows must be free from tuberculosis and other diseases.

But it is impossible to carry out these rules in practice. The city police does not extend to the country. There is need of state and imperial control of the production of milk. Municipal

× Compare the Italian law cited in my article, Am. Journal of Sociology, November, Igrr.

${ }^{2}$ Würtz, op. cit., 75 ff. 
monopoly of the business has been proposed by many conservative men because this would reduce the price of milk to the poor and guarantee pure quality.

\section{DAY NURSERIES (Krippen)}

The medical requirements in Germany do not differ from those of other advanced nations, and the technique is much the same in all good institutions. In most German cities crèches are supported by private charity. Often the "Inner Mission" is active in this field. ${ }^{x}$

\section{NURSLINGS' HOMES}

Infants abandoned must have at least temporary care in institutions. When the homeless and unmarried mother must go out to earn the means of living, or when she is sick, or when she dies, a nurslings' home is needed, with the facilities of an infant hospital.

In Austrian foundling asylums an infant is received at once and inquiry follows after the baby is safe. Austria has only a few large institutions, at Vienna, Graz, Prague. In Germany there is only one, the Kinderasyl at Charlottenburg.

Würtz and others urge the importance of nurslings' hospitals quite separate from children's hospitals. The nursling requires special arrangements of space, care, and feeding. Infection can be avoided only by particular methods of asepsis. Nurses must have a special training for such institutions.

Schlossmann, in order to secure the best air, established a forest hospital (Waldsäuglingsheilstätte). A floating hospital for babies has been planned.

In the hospitals it has been found that one wet nurse, with her own child, can nurse one or more others, especially where mixed food is used. Many women can produce three liters of milk a day. But even so an adequate supply of wet nurses cannot be found, and artificial feeding is introduced. This calls for a special kitchen for the preparation of such food.

The cost of nurses is somewhat reduced by employing intelligent apprentice nurses at low wages, for a course of three to twelve months.

${ }^{x}$ Schäfer, Leitfaden der inneren Mission. 
Weaklings, as those prematurely born with less than 2,000 gr. weight, must have special care. Infants with hereditary syphilis must be separated from the mother and kept four years in a special department of a hospital.

\section{EXTENSION OF PEDIATRIC INSTRUCTION}

There is complaint from specialists in Germany that provisions for study of nurslings and their diseases are not satisfactory. Of 20 universities only I 2 had a children's clinic, some of them poorly equipped. Only in II universities was the instructor a pediatrist, and most have only a general children's clinic for teaching. The medical examinations in this field are not adequate.

The situation in Austria is better: all the medical faculties have children's clinics, and examinations in children's diseases are obligatory. In Switzerland there are chairs of pediatrics; all except Fribourg have children's hospitals; but the subject is not required in examinations.

In the academies of Cologne and Düsseldorf there is pediatric instruction, but not for young physicians.

In this connection Würtz insists, and with wisdom, that physicians should study not only pediatrics but also social politics, "because the protection of nurslings is not the exclusive domain of medicine." The situation here described is rapidly changing for the better, and any statement of it is soon out of date.

POPULARIZING KNOWLEDGE OF CARE OF NURSLINGS

Germany has a large number of periodicals, scientific and popular, which deal with the subject. ${ }^{x}$

To bring all the isolated efforts into harmonious and effective co-operation central offices are established. ${ }^{2}$ They collect information, furnished expert advice, give attention to urgent cases, influence authorities to correct evils and give subsidies.

'Zeitschrift für Säuglingsfürsorge; Zeitschrift für Säuglingsschutz (since r9og), organ of the Kaiserin Viktoria-Haus and of the Deutsche Vereinigung für Säuglingsschutz; more popular are Blätter für Säuglingsfürsorge, organ for the Bavarian Zentrale für Säuglingsfürsorge; Mutter und Kind (in Düsseldorf); Weg (in Prussia).

${ }^{2}$ For example: Die Zentrale für den Regierungsbezirk Düsseldorf. 